\title{
The Remedial Right of Secession in International Law
}

JOEL DAY

University of Denver

\section{INTRODUCTION}

Secession and self-determination are two of the most contested issues in international affairs. Even as President Wilson endorsed the concept of selfdetermination, his own Secretary of State expressed concern that it would escalate into an unmanageable cascade of instability. The ensuing debate culminated in a widely accepted view articulated by Secretary-General Thant in 1970: "the United Nations has never accepted, and does not accept, and I do not believe it will ever accept the principle of secession of a part of its Member State" (UN Chronicle 2). Many scholars have also declined to interpret self-determination as an enforceable right, separating self-determination from the concept of partition. But is this really settled law? Does international practice really decline support of secession? Recent endorsement of South Sudan's breakaway and the internationally administered secession of Kosovo raise doubts. A study of this nature is timely, considering that ethnonational secessionist claims undergird almost 50 intra-state armed conflicts worldwide and secession is more common today than ever before. Considering Hewitt, Wilkenfeld and Gurr's study reveals that, "independence minded groups are more likely to fight wars than groups with other objectives," it is vital that scholars and practitioners embrace creative conflict resolution strategies for cases in the future" (Hewitt et al. 3). The purpose of this article is to identify the exact legal standing of secession, situate current practice in the context of secession theory, and then ultimately determine how the international community should respond to secession in the future.

Section one reviews the existing instruments of international law that deal with the issue of secession. This sets the foundation for an institutionally centered discussion of secession, as opposed to ethereal philosophising. The nature of 
the subject is more productively discussed in an institutional vernacular, focused upon law and precedent. I argue that precedents set by the International court of Justice (ICJ) have understood self-determination as the externally recognised self-governance of an insular, often oppressed, minority. Simply put, the ICJ has sanctioned secession as a tool to punish human rights violators and free oppressed peoples.

After identifying current practices of secession, section two proceeds as a discussion of first principles, centering on the theoretical debate between those who maintain secession as a primary right of a people and those who view it as a last ditch effort to preserve human rights. The section uses the international legal concepts of erga omnes and jus cogens as criteria to determine which school of thought most successfully upholds human rights. The crux of the matter is whether possessing a state is a universal right or if groups may only secede in response to human rights violations. Using erga omnes and jus cogens in this manner provides institutionally based criteria to judge philosophically-rooted schools of thought. The ultimate finding is that an 'ideal' formulation of secession is not so distant from the current legal practice. Section three builds on this conclusion and charts a path forward, linking theory and practice together for better policy in the future.

\section{WHERE ARE WE? SECESSION AND THE COURTS}

The legal discussion of secession is informed primarily by the rise of selfdetermination as a legal principle. In fact, there are competitive versions of selfdetermination. During the decolonisation process, self-determination was associated with a colonised people being freed from colonial institutions and establishing their own territorial government. However, examples soon emerged that confounded this definition. After the British left India, it became clear that Pakistan and India had divergent aims, which culminated in a violent partition; Bangladesh would later split from Pakistan in a similarly bloody manner. These examples, combined with the partition of North and South Sudan in 2011, indicate that a strictly anti-colonial definition is far too limiting; peoples with no prior history of direct colonial rule have seceded and received recognition. One could thus argue that secession is a function of external self-determination regardless of colonial past. On the other hand, one could argue that self-determination has merely internal qualities such as the right of a people to freely associate within their group, even if they are in a multiethnic state (Moore 1-14). For instance, Jan Klabbers has stated that selfdetermination has "evolved into a right of peoples to take part in decisions affecting their future" which is not secession, but some sort of democratic consociationalism 
(Klabbers 189). What is the correct interpretation, from an international standpoint, of secession?

Foundational documents of international law make reference to the right of a people to govern themselves, the most prominent examples being the League of Nations Charter, the Universal Declaration of Human Rights (UNDHR) and the Declaration of the Granting of Independence to Colonial Countries and Peoples. These documents each expand the legal claims of self-determination to all peoples. It therefore becomes imperative to genealogically trace the right of self-determination, and to determine under what circumstances peoples may seek external sovereignty and not merely internal arrangements.

The principle of self-determination quickly became a cornerstone in the normative development in the field of human rights (Brownlie 228). Recognising the "yearning for freedom in all dependent peoples [who have a] right to freely determine their political status," the UN has endorsed the concept that subjugated groups have the right to 'replace their status' with one of freedom (United National General Assembly Resolution 217A). The International Covenant on Civil and Political Rights also recognises an inherent right for 'national' self-determination, while Article 15 of the UNDHR affirms nationality as a fundamental human right. From the standpoint of international law, nationality and self-determination are the rights of individuals as well as solidarity or collective rights, as the Civil and Political Covenant indicates. This interpretation seems congruent with how the International court of Justice refers to the right to self-determination, which defines it as "a right held by people rather than a right held by governments alone" (International court of Justice, Advisory Opinion 12). The documents indicate that, as a collective right, peoples have a legal claim to their nationality and their status within a governmental institution. Yet to fully understand how these claims function legally, we must turn to precedent as a guide.

One of the first advisory opinions issued by the court concerned the colonial mandate relationship between South Africa and what is now known as Namibia (South-West Africa). Spanning from 1950 to 1971, the ICJ issued several opinions concerning the unequal apartheid-style development in Namibia, where white South Africa imposed restrictions and limitations solely upon grounds of national and ethnic origin. In 1966, the General Assembly, followed by the Security Council ordered the termination of the South-West African mandate, which was ignored by South Africa. The final opinion issued in 1971 by the Court confirmed that Namibia should be free from apartheid policy and recognised as an independent state. Namibia (1971) treats self-determination as an enforceable, tangible right - much 
more than any nondescript "right to be taken seriously" (Klabbers, 186). With much flourish, Judge Ammoun concurred with the opinion, citing that no fewer than fiftyfive states became independent since World War II because of how a principle of self-determination 'matured' with the 'blood of the peoples' (International Court of Justice, Namibia 69). Though the central issue of Namibia was not whether or not secession was legally justified, the case sets a strong precedent of support for persecuted peoples desiring self-governance - not one imposed from above. Namibia sets the stage for understanding self-determination as a way of giving selfgovernance to people violently denied it.

In Western Sahara (1975), the court again refrained from condoning splitting up a state, but indicated that there is a strong legal claim for "the principle of selfdetermination as functionalised in the free and genuine expression of the will of the peoples of [a] territory" (International Court of Justice, Western Sahara 68). This penultimate line of the opinion inherently democratizes the concept of selfdetermination, but its application is also unique to a territorially defined group. The example of Western Sahara indicates that a people can lay claim to territory and, more importantly, remain free from outside intrusion - a key function of external sovereignty.

Some scholars maintain that Western Sahara teaches a different lesson. Jan Klabbers argues that the court uses the term 'principle' as opposed to 'right', as a signal that self-determination does not have erga omnes implications, but operates as a suggestion (Klabbers 186-206). This interpretation misses two key facts. First, the court referred to "the principle of self-determination as a right of peoples" indicating that the ICJ understood self-determination to be a right of peoples codified by legal precedent stipulated in prior UN documents (International Court of Justice, Western Sahara 38). Second, Western Sahara was meant to assist the General Assembly in determining sovereignty over a decolonised territory amidst competing territorial claims. The fact that the court concluded by highlighting the right of selfdetermination of peoples within a territory shows that there is an intrinsic standard linking territory to the right of self-governance. Thus, by 1975, the court had thus made two key decisions that tie territorial claims to the notion of self-determination, making such a right much more than simply internal democratic recognition of subnational groups.

Eleven years after Western Sahara, the court was asked to decide the merits of a dispute between Mali and Burkina Faso based upon the principle of uti possidetis (territory remains with possessors after war). The court's opinion in Frontier Dispute (1986) was significant because it defined peoples entitled to self-determination as 
those who possess a reasonably defined area of land. Land possession is again a key defining characteristic of self-determination - consistent with Western Sahara and Namibia. Frontier Dispute goes further than these cases, however, by implying that a self-determining people have an intrinsic right to govern their heritage-land, reenforcing General Assembly Resolution 1514 which highlights the right of a collective people to freely determine their political status. The factors necessary to prove that a people have the right to external self-determination are fairly well defined by Frontier Dispute: First, a history of independence or self-rule in an identifiable territory; second, a distinct culture, and third, a will and capability to regain selfgovernance.

Finally, East Timor (1986) consolidates the above understanding of these matters. The dispute in question between Portugal and Australia was ultimately dismissed, though not before the court reaffirmed that the right to territorially based self-determination was a right erga omnes. The court found specifically that:

...the right of peoples to self-determination, as it evolved from the Charter and from United Nations practice, has an erga omnes character, is irreproachable. The principle of self-determination of peoples has been recognized by the United Nations Charter and in the jurisprudence of the court ...; it is one of the essential principles of contemporary international law (International Court of Justice, East Timor 102).

The principle of erga omnes mandates that territorial self-governance of a people is fundamentally incumbent on the international community to protect, even perhaps above state sovereignty in some instances.

The UN Human Rights Committee General Comment 12 endorses this view of self-determination as a right to be protected for everyone erga omnes. Yet, the committee applies the standard even more forcefully than the ICJ does in East Timor, stating, "the obligation exist irrespective of whether a people entitle to self-determination depends on a State party to the Covenant or not." Taking the Committee's comment in tandem with the East Timor decision implies that not only are signatory populations entitled to govern the territory in which they reside, but even if a rogue non-signatory state denies the people their right, the standard applies. In essence, not only is self-determination a right erga omnes, but also has a jus cogens character as well.

These cases outline a clear evolution in the understanding of selfdetermination. First, Namibia demonstrates that self-determination is a critical 
element of international law relating to people suffering from poor or oppressive government. Second, Western Sahara demonstrates that the right of a people to self-determination is a codified legal principle, tied directly to the land they identify with. Third, Frontier Dispute makes clear that not only do peoples have a selfdetermination right tied to land, but that they also have the right to govern that particular territory according to their general will. Fourth, East Timor finalises the status of self-determination by classifying it erga omnes - placing it on par with the rights of people to be free from torture and genocide. Especially after the Barcelona Traction case, which expanded the use of erga omnes rights to stand above the state claim of sovereignty, it is not a leap to maintain that the right for a people to possess and govern their own land trumps the principle of territorial integrity.

Occurring at the same time as Western Sahara, the Helsinki Final Act (1975) presents an interesting take on secession as a function of self-determination claims. As a major document of understanding between two superpowers, the few times Helsinki mentions self-determination should contribute significantly to a textual understanding of the issue in international law. In Section Eight, the agreement stipulates that self-determination possess both internal and external attributes, with an understanding that, "all peoples always have the right, in full freedom, to determine, when and as they wish, their internal and external political status, without external interference, and to pursue as they wish their political, economic, social and cultural development." Not only do people have a right of self-determination erga omnes and jus cogens, but that right is defined by a decision about territorial governance and external political status, without interference.

Although internationally sanctioned secession seems to function as a primary right of peoples independent of state-led oppression, international bodies have stopped short of endorsing such a policy. Several decisions and treaties have limited the application of self-determination as external sovereignty or secession. For example, the Badinter Commission was established in 1991 to answer the legal questions arising from disbanding of the Socialist Federal Republic of Yugoslavia. There are two important lessons from the Badinter Commission for the purposes of this study. First, the very existence of the commission sets a precedent for international involvement in the issue of secession. In light of the commission, the international community has a special obligation to establish such commissions as the cases arise. Although some have maintained that the Badinter Commission was designed only apply to cases of dissolution, not secession, a closer examination of the sequence of events reveals that Croatia and Slovenia left the Socialist Federal Republic of Yugoslavia (SFRY) a month before the commission recognised that the 
SFRY was in a process of dissolution; this indicates the observed events were actually secession, not dissolution (Radan 74).

A second lesson from the Badinter Commission is the issue of territorial integrity in the context of secession. The "Opinion Three" of the commission examines how frontiers are to be legally conceived at the point of secession. As previously mentioned, the commission was working under the legal precedents of Western Sahara, Namibia, Frontier Dispute and East Timor, as well as the Helsinki Final Act. The Badinter Commission determined that the borders of a seceding state are to be determined based upon the principle of uti possidetis, where the "existing internal federal borders of such federal units are transformed into international borders of the new state" (Radan 52). Although Peter Radan and others have argued that Opinion Three is legally unsound, existing precedent reveals it to be a logical extension of over 50 years of international case law. This principle of maintaining internal borders as the new international frontier, in the event of secession, has become a widely accepted international law. The decision of the 1998 Canadian Supreme Court 're: Québec' articulates a similar approach to the question. Although the conclusion of this case was that it would be illegal for Québec to secede, the Canadian Supreme court argued that if secession were legally recognised, international law would mandate that the internal borders would be the new international boundaries. Such was the case in four newest additions to the international community - Kosovo, Montenegro, East Timor, and South Sudan. Territorial governance and control is thus consistently a judicially recognised function of self-determination. The precedent for territorial separation from a state has been set very clearly. But under what conditions may a group legally secede?

While affirming the territorial governance aspect of self-determination, the Canadian case argues something that goes back to Namibia. The Canadian Supreme Court determined the illegality of secession based on the lack of 'incompatibility' between the central government and the Province of Québec; that is to say, the two governments worked well together. Quebecers were not oppressed by the central government, and maintained complete internal authority over language, education, cultural programs, and social development - those aspects of self-determination identified in Helsinki. In essence, because Quebecers exercised full and uninhibited internal self-determination, there was no need for external self-determination. Some sort of harm must be done for a population to be granted external recognition of its status. Case-studies of international law thus identify the following five principles: 
1. Self-Determination is a right of peoples, not merely a legal principle. (UNDHR, UNCESCR, Declaration on the Granting of Independence to Colonial Countries and Peoples)

2. Self-Determination belongs to those peoples who have been oppressed in some way (Namibia) and may be displayed as external sovereignty if there is harm being done by the center to the periphery Québec.

3. The Right to Self-Determination is linked directly to a defined and discrete territory (Western Sahara).

4. A Self-Determined people, living in a discrete territory have a codified right to govern said area according to the general will of that group (Frontier Dispute).

5. The right for a people to govern their territory and determine their internal and external status is a right erga omnes and jus cogens (the Helsinki Final Act and East Timor).

These core practices of international law seem to support only one conclusion: the abuse or neglect of minority self-determination by denying their territorially based self-governance is a supreme violation of human rights which must be protected by the international community. Although international law has stopped short of explicitly endorsing a primary right of a group to secede via plebiscite, these five principles indicate that secession is not only legal, but also imperative, if it is to remedy some sort of harm. It would seem that external self-determination can be a remedial exercise if a population is denied internal self-determination. The next section seeks to determine whether or not this status quo is sufficient to protect internationally defined universal human rights, or if a different system should be devised.

\section{WHERE SHOULD WE BE? THEORETICAL 'FIRST PRINCIPLES'}

Many scholars have contributed to a moral understanding of secession, but it is important to identify the main themes in this literature to determine whether or not current international precedent is on track or needs significant revisions in order to fit an appropriate normative model (See: Norman; Moore; Buchanan; Copp; Falk). There are two fundamental understandings of the issue. Just Cause or Remedial Rights theorists, like Allen Buchanan, maintain that secession is not justified except in cases of extreme abuse by a majority against a territorially concentrated minority. In contemporary international law, Just Cause theorists would be interested in partitioning states as a measure of protection for a minority population and would not be interested in breaking up a state that is democratically considerate of the 
minority territory. Choice Theory or Primary Right theorists, on the other hand, argue that secession is justifiable via association or ascription, through the mechanism of plebiscitary vote. Both strains of Choice Theory maintain a system where secession is nominally easy to accomplish for a group. Ascriptive Group Theories most often occur with a flare of ethnonationalism, concentrating on shared cultural characteristics and mutual heritage of history and language as justification for a split (See: Copp; Margalit). 'Associative Group' theorists, most notably, Daniel Philpott and Kai Nielson, liken the moral calculus of secession to that of a no-fault divorce. Nielson and Philpott make the argument that democracy and secession are intrinsically linked together on a philosophical level, and consequently, these scholars advocate that secession should be a natural process of self-determination.

Given the discussion thus far, we turn to the moral debate on secession, summarising how each school of thought fits into the international law framework by posing two fundamental questions. First, does the theory provide a framework that matches basic moral obligations of international law? For this criterion, we are concerned primarily with established moral codes among nations, which are the most accepted norms in the international community: erga omnes (rights deserved by all) and jus cogens (a norm from which no derogation is permitted). Second, does the theory provide an institutionally plausible and workable mandate for international actors? In other words: is it feasible to design an institution around the ideal? Can we bridge theory and practice? This consideration is secondary because moral questions are needed to help design institutions; the 'institutionally sensible' criterion does not explain how the concept of secession should function. As pointed out by primary right theorist David Copp, "to answer in a morally tenable way the question whether there ought to be an international legal right of secession, we need first to be clear about the conditions under which a group would have a moral right to secede" (Copp 222). The next section outlines such moral conditions for secession as defined in international law.

\section{SECESSION AS ERGA OMNES AND JUS COGENS}

Erga omnes are those rights that are universally applicable and enforceable. Such rights are distinct from contractual rights, where penalty can only be appraised upon a contracting party and enforced by the power of the other. Similarly, the term jus cogens holds the highest hierarchical position in international law and is generally referred to as a preemptory norm from which no derogation is permitted. According to the Vienna Convention on the Law of Treaties, any treaties or acts of states that conflict with these preemptory norms are void and punishable by Security council 
action. Although such obligations are not found in a single document, there is widespread consensus that jus cogens obligations that are erga omnes include bans on piracy, genocide, torture, and slavery. Most importantly, the norms are universal and binding to all persons and states, whether they are party to treaties on the issue or not. We have already established that several instruments of international law have treated aspects of self-determination with erga omnes characteristics. But does this extend to secession? Is an external self-determination erga omnes independent of any sort of internal harm being caused by the central state? Primary Rights theorists answer affirmatively.

Primary Rights theorists outline their case parsimoniously: Minority groups have a moral right to secede if they meet certain criteria. Scholars like Daniel Philpott argue that a plebiscitary vote of a concentrated minority territory is necessary. At the same time, should that group be determined to abuse the rights of their own minority groups - for example, Transdnestria partitioning from Moldova yet violating the minority Roma population within Dnester - then, Philpott maintains, they cannot make a legitimate claim to secede (Philpott 79). Such a viewpoint is rooted in a classical understanding of liberal autonomy and the harm principle. According to primary rights theorists, the state is a mirror of the autonomy of individuals and should apply the same democratic principles in relation to break away regions that it would in a referendum setting. Put more precisely, Philpott's normative value placed upon autonomy anchors the case for democratic governance and for a primary plebiscitary right to secede without first receiving injustice (Buchanan 16).

While understanding choice theory through the lens of autonomy might be conceptually helpful, it masks the deeper and more banal claims of this school of thought: Primary Rights theorists believe that groups have a right to secede simply if they have the preference to do so. As Copp explains, these "theories do not require that a group with the right to secede have been treated unjustly" (Copp 224). A group has a general right to secede in case it is a society that is both 'territorial' and 'political' in nature, capable of being able to successfully secede and form a viable state.

Primary rights theorists can thus be said to advocate for a system where a rump state must prove that: 1) a minority group wants to be a part of the state, 2 ) that those attempting to secede do not constitute a viable society, 3) that such people do not constitute any political organisation, and 4) that they do not possess territory. The burden of proof rests on the majority trying to keep counter-balance the exercising of self-determination by the minority (Nielson 103). This represents a problem of institutional implementation: if the burden of proof rests on the 
state-proper, then perverse motives exist for a state to brutally repress any signs of ethnonationalist organisation. It is imaginable, under these criteria, that a state would see even ethnic celebrations and festivals of solidarity as a potential threat to its rule. If all a state must do to retain territorial integrity is to prevent a regional group from possessing land and political organisation, there are a myriad of political tools available to state-rulers, from forced assimilation to genocide.

On a first principle level, does the Primary Right theory mesh well with the preemptory standards of erga omnes and jus cogens? The first theoretical problem that Primary Rights theorists encounter is that they seem to be arguing for the merits of statehood, rather than the rights that possessing a state afford to its citizens. To be clear, the possession of a state, or sovereignty, is not a human right, but rather, as articulated by the Responsibility to Protect (R2P) doctrine, is dependent on respect for human rights (Garrigues 2 ). States provide means to exercise individual and collective autonomy. As the UN Human Rights Committee has indicated, selfgovernment of a people is an 'essential condition' for the exercise and observance of other rights. On an institutional level, then, the UN has determined that the responsibility of a state encompasses the protection of rights. The breakdown of state legitimacy occurs at the point where it fails to protect and promote the rights of its inhabitants. In the case of self-determination, when states restrict the right for a territorially defined people to determine their own political status, they have failed in a primary duty. A minority has no erga omnes right to statehood and states have no jus cogens responsibility to provide statehood to populations. The only actual jus cogens obligation of a state concerns its treatment of the people.

It would seem that any erga omnes applications of a primary right to secede would be procedurally impossible, since there are no definitive standards on who deserves a primary right to secession. David Copp's suggestion that only territorial 'societies' can secede is nothing more than an arbitrary standard. Copp also asserts that secession is morally justified only if there is some significant chance of success. Yet, if a group does have a primary right based on their autonomy as suggested by copp and Philpott, this 'chance of success' principle is inherently unjust, because it hinges the exercise of a human right upon pragmatic calculation. In addition, such a standard changes the moral status of secession on a case-by-case basis. If erga omnes rights and jus cogens obligations mean anything, they mean that the principles are constant, predictable, and stable - they certainly do not change based upon the winds of pragmatism.

Remedial Right theorists, on the other hand, outline exactly when secession is morally justifiable. A group has the right to secede if the physical survival of its 
members is threatened by actions of the state. In essence, a group of people has no right to secede simply because it possesses land and wants political independence there must be documented cases of extreme harm being inflicted on the people in question. Such a use of secession arises as a response to serious grievances (Moore 41). For Remedial Rights theorists, secession is not a right in and of itself - it is a last ditch policy designed to protect other erga omnes rights, which bind states jus cogens. Secession is therefore useful because it can effectively force a state to respect the 'soft' self-determination of a minority. In the same way that possessing a state is meant to foster individual human rights, the pursuit of a state through secession is meant to achieve a larger goal than simply partition of a sovereign state - it is about protecting rights. This argument seems to mesh quite well with consensus understandings of how erga omnes rights function. In the case of state support of torture, war, genocide, or other crimes, the international community has taken steps to advocate for the protection of the people in jeopardy. Considering the precedents discussed in the section above, and the functionality of erga omnes rights, it makes sense to conclude that remedial rights theorists would view the policy of secession akin to peacekeeping operations.

The Remedial Right to secession could also be implemented at an institutional level quite easily: The ICJ could simply determine whether or not a claim was justified based upon whether or not the rump state acted appropriately in regards to their jus cogens obligations. In cases like Sudan, where the government has engaged in a consistent policy of ethnic war, remedial criteria would conclude that the South has the moral right to secede. In cases like Québec, where the Canadian government has granted vast autonomy and procedural equality - which we could label 'soft selfdetermination', the remedial criteria would conclude that Québec has no moral claim to any sort of hard, external self-determination.

An additional distinction between the remedial school and primary right school is appropriate here. The requirements outlined by primary theorists for justified secession present a problem of institutional implementation. The primary rights school opens a dangerous Pandora's Box of potential genocide at worst, and denial of language and culture at the best. If ascribed identity groups have a right to leave at any time, the state has a perverse incentive to violently root out those who would advocate for such a partition. Elimination of 'otherness' and denial of voice becomes a primary means of rooting out those identities that might claim a primary right. Remedial implementation offers the exact opposite scenario: Territorial integrity is a reward for proper treatment of minorities and is revoked for repression. If fully recognised, the remedial right of secession would guarantee that, 
if a state sought to repress a minority through violence, it would be assured to lose sovereignty over the very frontier they hoped to retain - almost functioning as an extension of R2P.

\section{WHERE CAN WE BE? CONTINUING AN INSTITUTIONAL FRAMEWORK}

If the remedial school of thought is correct and secession is to be granted only in cases of jus cogens violations, then how far away is the legal status quo from instituting this first principle? specifically, what must be done in order to align theory with practice? As it turns out, there are realistic strategies that can be pursued to accomplish this.

The case of South Sudan highlights how a remedial right understanding of secession fits perfectly within the existing framework of international humanitarian law. Hardly any institutional change is necessary to institutionalise the principles of remedial secession. The cases discussed above indicate that a foundation has been set for understanding secession as the external manifestation of self-determination, especially in the context of protecting populations from harm. Certainly the discussion on case law in section one supports this view as well. One minor change, however, may clearly demarcate the ending of the primary/remedial debate, and usher in a new era for the international community on the issue.

On 27 November 1961 the UN passed resolution 1654 which established a special committee on the Implementation of the Declaration on the Granting of Independence to Colonial Countries and Peoples. After the committee reviewed over 50 cases of occupied territories, the General Assembly abolished the committee in 1964. A wise first step towards linking the UN agenda on human rights to current international law would be to resurrect this now defunct oversight committee to review the situation of non-self-governing peoples. As we saw in discussion on the Badinter Commission, the international community has certainly played this role before. This group would provide the independence and management necessary to fully map secessionist claims and provide a supporting architecture. This committee would not arbitrate cases, but, keeping in mind that remedial claims come with high levels of violence and war crimes, seek to document the humanitarian case against the rump state. Likewise, the committee could track the behavior of the seceding state. Just as other human rights issues like slavery and rights of women have Special Representatives or committees that examine abuses, a committee looking to map secessionist claims would have a specialised agenda and would have regional specialists to support its mandate. Establishing a new oversight mechanism is important, since existing international bodies such as the Committee Against Torture and Committee 
of Human rights exist to promote and monitor existing conventions. Since no such convention exists for secession, a new framework based upon the cases discussed above is necessary. After an arbitrating body like the ICJ grants a partition based on evidence accumulated, this committee could turn its attention to socialising the new state into the international community. In addition, to hasten the consolidation of secession as a remedial right, the ICJ could establish special rules of standing for those self-determined populations who have been persecuted in some way.

\section{CONCLUSION}

The debate about the right of secession in international law is coming to an end. ICJ precedent indicates that while there is no 'primary' right for a population to secede, the international community has taken the steps to endorse secession when a state commits crimes against humanity against a territorially concentrated minority. This situates existing case law firmly in the remedial rights camp. By evaluating secession theory through the lens of erga omnes and jus cogens, this article has attempted to argue that theory and practice are generally congruent and that they are situated on the side of a remedial justification for secession. As seen in both Kosovo and South Sudan, secession became the option of last resort for the international community, once it was clear that rump states of Serbia and Sudan had committed serious crimes. Internationally recognised secession, therefore, operates akin to the R2P doctrine, where sovereignty and territorial integrity are dependent upon upholding the rights of citizens.

Although outside the scope of this study, future scholarship should concentrate on fundamental questions resulting from a remedial view of international law on secession. For instance, more work needs to be done determining what constitutes justified secession. What, precisely, is the threshold of atrocities and abuses at which the international community recognises the need for secession? The cases discussed here suggest a fairly high threshold for violence. After further study and theoretical development, some scholars may determine that the necessary preconditions for secession should include violations of a less arduous character. To this end, it may be prudent for the international community to establish an arbitration commission to address the unique claims of self-determination. Even if such a body is never constructed, however, it will be difficult to reverse several decades of legal development on the issue. The international community, wittingly or not, has created a legal norm around the concept of self-determination that endorses secession as an answer to rights violations. 


\section{WORKS CITED}

Belgium v. Spain (Barcelona Traction: Second Phase). International Criminal Court, 1970.

Brownlie, Ian. Basic Documents in International Law. New York: Oxford University Press, 2009.

Buchanan, Allan. Secession: The Morality of Political Divorce from Fort Sumter to Lithuania and Quebec. Boulder, CO: Westview Press, 1991.

Buchanan, Allan. "Democracy and Secession." National Self Determination and Secession. Ed.Margaret Moore. New York: Oxford University Press, 1998. 103-133.

Copp, David. "International Law and Morality in the Theory of Secession." The Journal of Ethics 2.3 (1998): 219-245.

Falk, Richard. "Self Determination Under International Law: The Coherence of Doctrine Versus the Incoherence of Experience." The Self Determination of Peoples: Community, Nation, and State in an Interdependent World. Ed. Wolfgang Danspeckgruber. Boulder, C0: Lynne Rienner Publishers, 2002: 31-67.

Burkina Faso v. Mali (Frontier Dispute). International Court of Justice, 1986.

Garrigues, Juan. "The Responsibility to Protect: From an Ethical Principle to an Effective Policy." FRIDE, Nov. 2007. http://www.fride.org/publication/298/the-responsibility-to-protect:-from-an-ethical-principle-to-an-effectivepolicy. Accessed on 11 Jan. 2012.

Hewitt, Joseph, Jonathan Wikenfeld, and Ted Robert Gurr, eds. Peace and Conflict 2010. Baltimore: Center for International Development and Conflict Management, 2010.

Klabbers, Jan. "The Right to Be Taken Seriously: Self-Determination in International Law." Human Rights Quarterly 28.1 (2006): 186-206.

Kofman, Daniel. "The Rights of Secession." Society 35.5 (1998): 30-37.

Namibia (Legal Consequences for States of the Continued Presence of South Africa in Namibia Advisory Opinion). International Court of Justice, 1970.

Margalit, Avishai, and Joseph Raz. "National Self-Determination." The Journal of Philosophy 86 (1990); 439-461.

Moore, Margaret. "The Self-Determination Principle and Ethics of Secession." National Self Determination and Secession. Ed. M. Moore. New York: Oxford University Press, 1998. 1-14.

Nielson, Kai. "Liberal Nationalism and Secession." National Self-Determination and Secession. Ed. Margaret Moore. New York: Oxford University Press, 1998. 103-133.

Norman, Wayne. "The Ethics of Secession as the Regulation of Secessionist Politics." National Self-Determination and Secession. Ed. Margaret Moore. New York: Oxford University Press, 1998. 34-62.

Parker, Karen. "Understanding Self-Determination: The Basics." 1st International Conference on the Right to SelfDetermination, Geneva, August 2000.

Philpott, Daniel. "Self-determination in Practice." National Self-Determination and Secession. Ed. Margaret Moore. New York: Oxford University Press, 1998. 79-102.

Portugal v. Australia (The Case Concerning East Timor: Summaries of Judgments, Advisory Opinions and Orders). International Court of Justice, 1986.

Radan, Peter. "Post-Secession International Borders: A Critical Analysis of the Opinions of the Badinter Arbitration Commission." Melbourne University Law Review 24.1 (2000): 50-76.

Reference Re: Secession of Quebec. 2 S.C.R. 217. Supreme Court of Canada, 1998.

United Nations. Human Rights Division. Universal Declaration of Human Rights. New York: United Nations, 1948.

United Nations. Treaty Series. The International Covenant of Civil and Political Rights. New York: United Nations, 1966.

United Nations. Treaty Series. The International Covenant on Economic, Social and Cultural Rights. New York: United Nations, 1976

United Nations. Human Rights Committee. General Comment 12. Article 1. U.N. Doc. HRI/GEN/1/Rev.1 at 12. New York: United Nations, 1994.

United Nations Office of Public Information. "Statement of Secretary General Thant." Monthly Chronicle 2 (1970): 2.

Western Sahara (Advisory Opinion 12). International Court of Justice, 1975. 
